УДК 378.14:81

DOI:

Борис Савчук, доктор історичних наук, професор, професор кафедри педагогіки імені Богдана Ступарика Прикарпатського начіонального університету імені Василя Стефаника Галина Білавич, доктор педагогічних наук, професор, професор кафедри педагогіки початкової освіти Прикарпатського національного університету імені Василя Стефаника Світлана Яців, кандидат педагогічних наук, дочент кафедри англійської філології Прикарпатського національного університету імені Василя Стефаника Олеся Власій, докторант Прикарпатського наџіонального університету імені Василя Стефаника

\title{
ПРОБЛЕМА САМООСВІТИ МАЙБУТНЬОГО ВИКЛАДАЧА ВИЩОЇ ШКОЛИ В РЕЦЕПЦІЇ УКРАЇНСЬКОЇ ПЕДАГОГІЧНОЇ ДУМКИ
}

Розвиток інформаційних і освітньо-педагогічних технологій, нарощування нових знань у всіх галузях науки, підвищення вимог до підготовки конкурентоспроможного фахівця актуалізують проблему вивчення теорії і практики самоосвіти майбутнього педагога.

В основу його аналізу покладена модель, щуо складається з трьох систем координат, які передбачають: “по вертикалі” - з'ясування еволючії поглядів на самоосвіту у процесі розвитку суспільної $і$ педагогічної думки з акцентом на періоді 90-х рр. ХX-початку XXI cm.; “"по горизонталі”-узагальнення основних підходів, рефлексій, дефініцій изього феномена як складника професійної підготовки майбутніх викладачів; “по діагоналі" - синтез означених та інших аспектів крізь призму науково-педагогічного дискурсу.

Ключові слова: самоосвіта; самостійна робота; самоосвітня діяльність; самовиховання; науковопедагогічний дискурс.

Jim. 13.

Borys Savchuk, Doctor of Sciences (History), Professor of the Bohdan Stuparyk Pedagogy Department, Vasyl Stefanyk Precarpathian National University

Halyna Bilavych, Doctor of Sciences (Pedagogy), Professor of the Pedagogy of Primary Education Department, Vasyl Stefanyk Precarpathian National University Svitlana Yatsiv, Ph.D.(Pedagogy), Associate Professor of the English Philology Department, Vasyl Stefanyk Precarpathian National University Olesya Vlasiy, Doctoral Student, Vasyl Stefanyk Precarpathian National University

\section{THE PROBLEM OF SELF-EDUCATION OF A FUTURE HIGHER} SCHOOL TEACHER IN RECEPTION OF THE UKRAINIAN PEDAGOGICAL THOUGHT

Development of informational, educational and pedagogical technologies, increase of new knowledge in all branches of science, toughening up the requirements for preparation of competitive specialist causes actualization of the problem of studying the theory and practice of future teacher's self-education.

The purpose of the article is to carry out a substantive synthesized analysis of the scientific literature on the problem of self-education of the future high school teacher in order to determine the main approaches to its study and interpretation and ways of further research of this phenomenon.

Its analysis is based on a model consisting of three coordinate systems, which are: "vertically"-finding out the evolution of views on self-education in the process of development of social and pedagogical thought with a focus on the period of the 90's of XX cantury to early XXI century; "horizontally" - a generalization of the basic approaches, reflections, definitions of this phenomenon as a component of professional training of future teachers; "diagonally" - a synthesis of identified and other aspects through the prism of scientific and pedagogical discourse.

The main stages of the evolution of views on self-education in the context of the development of global and Ukrainian social and pedagogical thought are outlined. The main approaches to the study and interpretation of self-education are defined and characterized as: 1) similar, but not identical category to such concepts as "individual work" and "self-educational activity"; 2) individualized process of personal and professional improvement; 3) 


\section{ПРОБЛЕМА САМООСВІТИ МАЙБУТНЬОГО ВИКЛАДАЧА ВИЩОӤ ШКОЛИ В РЕЦЕПЩЇ УКРАЇНСЬКОӤ ПЕДАГОГІЧНӦ̈ ДУМКИ}

variety, method, form, means of cognitive activity; 4) means of professional competence formation; 5) component of long-life education; 6) one of the manifestations of the process of self-education; 7) revelation of person's self-esteem and self-organization; 8) forms and means of mastering by modern educational technologies, etc.

Keywords: self-education; individual work; self-educational activity; self-education; scientific and pedagogical discourse.

$\Pi$ остановка проблеми у загальному вигляді. Динамічний розвиток нових інформаційних і освітньо-педагогічних технологій, нарощування знань у всіх галузях науки, ускладнення і підвищення вимог до підготовки конкурентоспроможного фахівця, складні процеси реформування системи освіти України і їі інтеграції у європейський культурний простір, чергові виклики, що стоять перед українським суспільством і кожною особою зокрема, актуалізують проблему iї самоосвіти. Особливої гостроти вона набуває в процесі підготовки і професійної діяльності вчителя, якому, за висловом К. Ушинського, “треба постійно вчитися самому”, бо він “живе до тих пір, доки вчиться, як тільки він перестає вчитися, у ньому вмирає вчитель”.

Упродовж розвитку суспільної і педагогічної думки зусиллями сучасних учених нагромадився значний обсяг наукової і навчальної літератури 3 проблеми самоосвіти. На цьому тлі зростає “поліфонія", суперечливість, контроверсійність наукового дискурсу навколо цього феномена, що зумовлює потребу його предметного аналізу.

Мета і завдання дослідження полягають у здійсненні предметного синтезованого аналізу наукової літератури з проблеми самоосвіти майбутнього педагога задля визначення основних підходів до їі вивчення і шляхи подальшого дослідження.

Методи дослідження: контент-аналіз, вибірковий аналіз джерел, структурно-порівняльні та історіографічні методи, які забезпечують систематизацію, синтез, узагальнення та зіставлення наукової інформації.

Виклад основного матеріалу. Проблема самоосвіти універсальна, позаяк стосується всіх сфер людських знань, комплексна, позаяк охоплює розмаїття аспектів психофізіологічного розвитку особистості, ії професійної діяльності й особистого життя, має міждисциплінарний характер, позаяк $\epsilon$ предметом дослідження представників різних галузей знань; вона має понад двохтисячолітню традицію осмислення. 3 таких позицій підходимо до з'ясування сучасного науково-педагогічного дискурсу питання самоосвіти майбутніх педагогів вищої школи.

Оскільки означеному феномену присвячено значний масив наукової літератури з різних галузей педагогіки, яка, своєю чергою, інтегрує і адаптує доробок представників різних галузей гуманітаристики, для ¥іi аналізу пропонуємо модель, що складається 3 трьох систем координат: “по вертикалі" - з'ясування еволюції поглядів на самоосвіту у процесі розвитку суспільної і педагогічної думки з акцентом на періоді 90-х рр. ХХ - початку XXI ст.; “по горизонталі" - узагальнення основних підходів, рефлексій, дефініцій цього феномена як складника (підсистеми) професійної підготовки майбутніх педагогів; “по діагоналі”, що передбачає синтез означених та інших аспектів крізь призму сучасного науково-педагогічного дискурсу.

Генезу ідеї про потребу самовдосконалення і самонавчання впродовж життя науковці виводять зі священних текстів Біблії, Корану, Хадісах, які акцентували на їі моральних аспектах. Наближене до сучасного розуміння проблеми самоосвіти сягає коріннями доби Античності, коли давньогрецькі мислителі Архімед, Сократ, Платон утвердили постулат, згідно з яким розвиток мислення людини здійснюється якісно у процесі самовдосконалення, яке можливе лише на основі самопізнання. У класичному творі “На одинці зі собою” Марк Аврелій (II ст. н. е.) стверджував, що шлях до духовного вдосконалення людини пролягає через усебічну освіту, тому своє дозвілля вона має використовувати для постійного свідомого навчання [7].

Періодизації розвитку уявлень про самоосвіту в педагогічній думці акцентують на умовних періодах: IX - XV ст. - формування фрагментарних уявлень про неї в контексті церковно-релігійних канонів; XVI - XVIII ст. створення перших наукових теорій самоосвіти; друга половина XVIII - перша половина XIX ст. - вироблення самоосвітніх концепцій [9, 147]. Конкретизуючи їхнє змістове наповнення відзначаємо внесок в осмислення цього феномена Ж.-Ж. Руссо, Й. Г. Песталоцці, Дж. Локка, які вважали самостійну пізнавальну діяльність основнимзасобом розвиткуособистості, аГ.Сковорода (у такому контексті) ствердив хрестоматійний постулат: якщо хочеш виміряти небо, землю та море, починай з виміру себе.

Предтечею сучасних педагогічних уявлень про самоосвіту стали ідеї класиків педагогіки. Першу парадигму неперервної освіти Я.-А. Коменський виклав у метафоричному вигляді: як для "роду людського весь світ - це школа від початку до 


\section{ПРОБЛЕМА САМООСВІТИ МАЙБУТНЬОГО ВИКЛАДАЧА ВИЩОӤ ШКОЛИ В РЕЦЕПЦЇ УКРАЇНСЬКОЇПЕДАГОГІЧНОЇ ДУМКИ}

кінця століть”, так і для “кожної людини її життя - школа від колиски до труни”; “кожен вік призначений для навчання, й одні й ті ж межі відводяться для людського життя і школи" [6]. Розробку ¥ї психолого-педагогічних засад започаткував А. Дістервег (1835), який наголошував, що високого рівня підготовки педагогів можна осягнути лише за умови систематичної самоосвіти й постійного самовдосконалення, адже освіта не є чимсь завершеним, а завжди перебуває у стані становлення і змін. Учений сформулював стрижневий постулатів цього процесу: навчання інших для самого вчителя “ $є$ школою самоосвіти”, бо "ніхто не може дати іншому того, чого не має сам" [5, 201].

Класики української педагогіки К. Ушинський, О. Духнович, С. Русова, інші ввели компонент самоосвіти в теорію національної освіти. Ї̈̈ сутність, зміст, завдання вони зводили до самостійного набуття знань з української історії, культури, мови, літератури, фольклору; розглядаючи самоосвіту як форму і засіб саморозвитку особистості, спричинилися до розробки відповідних читанок і часописів “для народу”. Систематизований у них матеріал 3 різних галузей знань стимулював формування пізнавальної активності, самостійності мислення, інтересу до читання.

У зарубіжній та українській педагогічній думці кінця XIX - початку XX ст. утвердився погляд, згідно з яким головним засобом самоосвіти $€$ книга, тому основна діяльність у цьому напрямі зводилася до самостійного читання. У такому ракурсі до цього питання підходив К. Ушинський, який, говорячи про важливість самоосвітньої праці педагога, доводив, що постійне читання фахової літератури сприяє поєднанню педагогічних знань iз практикою та підвищенню рівня і якості навчально-виховного процесу [13].

Нові свіжі ідеї і широту поглядів на самоосвіту педагога засвідчив Великий Гуманіст XX сторіччя В. Сухомлинський, який розумів цю проблему як єдність і безперервність процесу оволодіння знаннями під час професійної підготовки педагога та його подальшу самостійну інтелектуальну працю над книгою. У цьому цілісному безперервному поступі формується особистість майбутнього фахівця, виробляються його нахили, здібності, моральні цінності, громадянська позиція $[12,350]$.

Абстрагуючись від дискусій щодо часу появи й авторства терміна "самоосвіта", констатуємо факт його існування в суспільній думці в 30-40-х рр. XIX ст. Так, у словнику С. Ожегова (1849) подається його тогочасне розуміння як “набуття знань шляхом самостійних занять без допомоги викладача" [8, 604], хоча в суспільній думці існувало й його інше розуміння.

Радянська наука урізноманітнила погляди на самоосвіту. У “Великій радянській енциклопедіі” (1975) та академічному “Педагогічному словнику” (1986) вона трактувалася в подібному ракурсі: як “самостійна освіта”, що орієнтує на здобуття системних знань 3 науки, техніки, культури, політичного життя шляхом самостійного вивчення матеріалу; як “освіта, яку здобувають поза навчальними закладами шляхом самостійної роботи" [1].

У наукових працях самоосвіта розглядалася в ширшому діапазоні, у якому умовно окреслюємо два основні напрями. Представники першого розглядали їі як окремий компонент освітнього процесу, що має свій зміст, етапи становлення і розвитку, науково-методичні й організаційна засади, джерела тощо. Така позиція в концентрованому вигляді випливає 3 доробку А. Громцевої (1977), яка трактувала самоосвіту як систематичну цілеспрямовану пізнавальну працю людини, що здійснюється окремо і паралельно 3 навчальною і професійною діяльністю для підвищення професійного рівня і задоволення пізнавальних потреб [4].

Адептів другого, більш еклектичного напряму об'єднує розгляд різних аспектів самоосвіти в контексті самовдосконалення і самовиховання особистості. Отже, ці поняття якщо не ототожнювалися, то у багатьох ракурсах вважали доволі подібними (А. Арет, Л. Рувінський та ін.).

Спільним для представників цих напрямів стало апелювання і розвиток ідей відомого російського вченого, бібліофіла і лідера руху за самоосвіту 80 - 90-х рр. ХІХ ст. М. Рубакіна (1862 - 1946). Його думки про те, що самоосвіта може замінити шкільну освіту, безумовно, не популяризувалися, однак активно розроблялися висловлені ним ідеї про ії індивідуальний характер; про потенціал книги як чинника, що активізує пізнавальні інтереси, мислення; про потребу критичного ставлення до прочитаного і чужих думок. У такому сенсі за сучасних умов розвитку Інтернет-самоосвіти актуальними залишаються систематизовані у виданій 1962 р. книзі М. Рубакіна “Як займатися самоосвітою" роздуми над сутністю цього феномена та практичні поради щодо “вибору і мистецтва

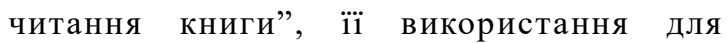
інтелектуального розвитку та естетичного самовиховання [10].

Отже, стислий синтезований огляд 


\section{ПРОБЛЕМА САМООСВІТИ МАЙБУТНЬОГО ВИКЛАДАЧА ВИЩОЇ ШКОЛИ В РЕЦЕПЩЇ УКРАЇНСЬКОЇПЕДАГОГЧНОӦ ДУМКИ}

досліджуваної проблеми самоосвіти в першій системі координат, “по горизонталі”, засвідчує іiі глибокі гносеологічні коріння та продукування розмаїття поглядів на неї.

Переходячи до розгляду проблеми самоосвіти в системі координат “по вертикалі”, констатуємо, що, спираючись на попередній досвід іiі осмислення, сучасна педагогічна наука, нагромадила значний пласт науково-теоретичних і навчально-методичних студій із цієї проблеми. Його синтез і структурування викликає значні труднощі, зважаючи на численні контроверсійні наукові рефлексії. Виходячи 3 цього, виокремлюємо основні підходи до вивчення і трактування самоосвіти як: 1) категорії близької, але не тотожної поняттям “самостійна робота" i “самоосвітня діяльність”; 2) індивідуалізованого процесу особистісного i професійного вдосконалення; 3) різновиду, методу, форми, засобу пізнавальної діяльності; 4) засобу формування фахової компетентності; 5) складника неперервної освіти; 6) одного з виявів процесу самовиховання; 7) прояву самооцінки особистості і іiі самоорганізації; 8) форми та засобу опанування сучасними освітніми технологіями й ін.

3'ясовуючи сутнісно-змістові характеристики цих компонентів, передусім відзначмо утвердження міждисциплінарного підходу до вивчення самоосвіти, що виявляється в доробку різних галузей знань, де вона розглядається як феномен розвитку людини та як складник освітнього процесу.

У цікавих і корисних для педагогічної науки філософсько-культурологічних студіях самоосвіта визначається як інформаційно-забезпечувальна діяльність 3 нагромадження, засвоєння, упорядкування, систематизації і відновлення знань для задоволення пізнавальних потреб особистості. Ïї роль у житті особистості та суспільства розкривається через низку соціальних і освітніх функцій (загальнокультурна, загальноосвітня, професійна; оптимізації використання вільного часу; адаптивна, компенсаторна, терапевтична тощо), які реалізуються в єдності і дозволяють оптимально розв'язувати перспективні, короткоi довготермінові ситуаційні суспільно й індивідуально значущі завдання (О. Бурлака [2, 11-13]).

Із соціології вчені-педагоги активно адсорбують пропаговані представником i фундатором цієї галузі знань (Г. Спенсером) ідеї, які ототожнюють самоосвіту із процесом природного інтелектуального саморозвитку цивілізації: людство може успішно розвиватися лише шляхом самоосвіти. Учений трактував їі як процес і спеціально організовану самодіяльну, системну пізнавальну діяльність; як показник культурного поступу; як складник самовдосконалення і самовиховання людини [11].

Найпоширенішим і найбільш конроверсійним $\epsilon$ перший, визначений нами науковий підхід до вивчення і тлумачення самоосвіти. Аналіз показав, що більшість учених відмовилася від їі ототожнення із самостійною роботою, яку розглядають як одну з форм, засобів самоосвіти. Самостійна робота рефлексується як така, що готує особистість до самонавчання, утверджує іiі самостійність, організованість. Ці компоненти розглядаються як складники та умови самоосвіти, яка (у цьому випадку) трактується як процес продовження і поширення навчання, що збагачує інтелект та сприяє розвитку майбутнього педагога відповідно до його соціальних, професійних, індивідуальних потреб. Так само науковці відмежовують самоосвіту від поняття “самоосвітня діяльність”, яке визначає “технологічні і змістові аспекти” (умови організації, методика тощо) процесу самопідготовки (О. Василенко, 2008; І. Сидоренко, 2006; Н. Сидорук, 2001 та ін.).

Подібність трьох означених понять має сенс, якщо самостійну роботу розглядати як цілеспрямовану, плановану, належно організовану діяльність з набуття і вдосконалення знань, умінь і навичок, необхідних для майбутньої вчительської праці. У цьому випадку самоосвіта виступає як професійна функція, що слугує підвищенню рівня педагогічної майстерності. Така позиція суголосна 3 поширеною в науковій літературі позицією, яка рефлексує самоосвіту як освіту, що набувається в процесі самостійної роботи без проходження систематичного курсу навчання в стаціонарному навчальному закладі, як його невід'ємний складник, що сприяє поглибленню, розширеннюіміцномузасвоєннюзнань(С.Гончаренко, 1997).

Другий і третій підходи щодо розуміння самоосвіти як індивідуалізованого процесу особистісного і професійного вдосконалення та різновиду, методу, форми, засобу пізнавальної діяльності в наукових студіях часто розглядаються в одному ключі. Спираючись на науковий досвід соціальної психології, ученіпедагоги акцентують на їі ролі і значенні для розвитку мислення і внутрішнього світу особистості, що відбувається лише у процесі їі постійного вдосконалення і сприяє формуванню професійного досвіду (Я. Черньоков, 2002 та ін.); на функціональному значенні самоосвіти, що забезпечує розширення професійного світогляду, 


\section{ПРОБЛЕМА САМООСВІТИ МАЙБУТНЬОГО ВИКЛАДАЧА ВИЩОЇ ШКОЛИ В РЕЦЕПЦЇ УКРАЇНСЬКОЇ ПЕДАГОГІЧНОЇ ДУМКИ}

виступає критерієм оцінювання навчальних досягнень студентів, мотивує самовдосконалення і професійне зростання педагога по закінченні вишу, сприяє нарощуванню знань за сучасних умов інформаційної глобалізації (Т. Медведовська, 2010).

У руслі сучасної освітньої парадигми найактивніше розробляються четвертий і п'ятий 3 означених підходів, вони збирають найбільше прихильників. Доволі конроверсійним видається компетентнісний підхід, згідно з яким самоосвіта майбутніх педагогів розглядається в “широкому” значенні: як постійна діяльність, спрямована на розширення і поглиблення всього комплексу знань, умінь, навичок з формування професійної компетентності майбутнього фахівця. 3 таких позицій розглядаються її основні науковотеоретичні параметри: принципи (цілісності і системності; практично-орієнтованої діяльності; відповідності змісту самоосвіти і рівня компетентності; самореалізації; раціональності тощо); функції (вироблення, розширення, удосконалення компетентностей педагогічної діяльності й особистісного потенціалу); умови формування потреби майбутніх педагогів у здійсненні самоосвіти (усвідомлення значення і потреби такої діяльності; формування необхідних для самонавчання навичок; залучення до активної практичної діяльностітаін.)(Л.Задорожна,О. Овчарук, Л. Сисоєва, О. Пометун та ін.).

Серед представників п'ятого підходу існує розмаїття поглядів на співвідношення понять “самоосвіта" і “неперервна освіта": від їхнього ототожнення (що ми принципово заперечуємо) до безлічі рефлексій, які відображають тісний зв'язок і взаємопереплетення цих феноменів. У другому випадку самоосвіта розглядається як: функція, що забезпечує реалізацію принципу “освіта впродовж життя”, сприяючи нарощуванню знань відповідно до наукового і технологічного поступу (Д. Жарилгапова); засіб постійного оновлення знань у процесі неперервної освіти, форма додаткової професійної підготовки або перепідготовки; процес, що починається в ранньому віці, триває впродовж життя і забезпечує зв'язок між шкільною і позашкільною формами освіти (Г. Зборовський, А. Мушинська, О. Шулкіна) та ін.

Шостий підхід щодо розгляду самоосвіти як одного 3 виявів процесу самовиховання популяризувався радянськими науковцями i продовжує розроблятися багатьма сучасними вченими-педагогами (Н. Ничкало, 2003 та ін.), зокремавконтексті культурології(О.Газман,П.Осипов). Він має сенс, якщо не ототожнювати ці феномени, а розглядати самовиховання як свідоме прагнення особи до засвоєння розмаїття соціального досвіду (культури), що реалізується за допомогою самоосвіти, яка в цьому випадку виступає як спосіб, форма, засіб досягнення означеної мети.

Сьомий з черги підхід щодо розуміння самоосвіти як вияву самооцінки особистості і їі самоорганізації в інтегрованому вигляді представила Н. Бухлова через сукупність різних “само": самооцінка; самооблік; самовизначення; самореалізація; самокритичність; самоконтроль; самоорганізація як уміння знайти джерело пізнання, раціональне використання часу, упорядкування робочого місця і діяльності; саморозвиток як результат самоосвіти [3]. Такий підхід невиправдано звужує предметне поле самоосвіти, тож означені “само" доречніше розглядати як іiї складники.

Останній, восьмий, підхід до розуміння i трактування самоосвіти як форми і засобу опанування сучасними освітніми технологіями стає дедалі популярнішим за сучасних умов їхного бурхливого розвитку. Він має сенс, якщо абстрагуватися від спроб звести самоосвіту до інтернет-освіти (які значно звужують їі функціональне поле), адже новітні інформативні технології спричинили справжню революцію в самоосвітній діяльності. Завдяки майже необмеженим можливостям доступу до різногалузевих знань і швидкої передачі інформації вони кардинально модернізують потенціал і методи самоосвіти та актуалізують потребу опанування знаннями і навичками пошуку та оперування інформацією в інтернеті, який стає одним 3 основних і найпотужніших засобів оптимізації всього освітнього процесу.

Висновки та перспективи подальших досліджень. Обмежені межі статті дозволяють лише у стислому концентрованому вигляді окреслити процес еволюції осмислення самоосвіти в розвитку суспільної і педагогічної думки та основні підходи до їі вивчення в сучасній науково-педагогічній науці. Запропонований синтезований аналіз дає підстави для висновку, що жоден з означених підходів у своєму конкретному вимірі апріорі не може відобразити всієї повноти цього складного багатоаспекного феномена, який постійно змінюється, модернізується в контексті чергових освітніх і суспільних викликів. Тому всі спроби предметного комплексного вивчення самоосвіти мають мати міждисциплінарно-акумулятивний характер у напрямі синтезу його продуктивних наукових рефлексій. Перспективи вивчення цієї проблеми вбачаємо в аналізі нагромадженого в різних 
галузях знань доробку про феномен самоосвіти, який доцільно творчо адаптувати до потреб теорії і практики педагогічної науки і освіти.

\section{ЛІТЕРАТУРА}

1. Большая советская энциклопедия. Москва, 1975. T. 22. 627 c.

2. Бурлука О. В. Самоосвіта особистості як соціокультурне явище : автореф. дис. канд. філос. наук: спец. 17.00.01 “Теорія та історія культури”. Харків, 2005. 16 с.

3. Бухлова Н. В. Організація самоосвітньої діяльності учнів. Харків, 2003. 64 с.

4.Громцева А.К.Самообразованиестаршеклассников общеобразовательнойшколы. Ленинград, 1977. 119 с.

5. Дистервег А. Руководство к образованию учителей. Москва, 1989. 412 с.

6. Коменский Я. А. Избранные педагогические сочинения. Москва, 1982. Т.1. 656 с.

7. Марк Аврелій. На одинці з собою. Роздуми. Львів, 2007. 212 с.

8. Ожегов С. И. Словарь русского языка Москва, 1986. 798 с.

9. Пилипенко Є. О. Самоосвіта як педагогічна проблема. Наукові записки. 2011. Вип. 27. С. 145150. URL: http://nbuv.gov.ua/UJRN/Nzkp_2011_ 27 22

10. Рубакин Н. А. Какзаниматься самообразованием. Москва, 1982.127 с.

11. Спенсер Г. Опыты научные, политические и философские. Москва, 1999. 1408 с.

12. Сухомлинський В. О. Народження громадянина. Вибр. тв.: В 5-ти т. Київ, 1977. Т. 3. С. 283-582.

13. Ушинский К.Д. О пользе педагогической литературы. Собр. соч. в 2-х т. Москва, 1988. T. $2.512 \mathrm{c}$.

\section{REFERENCES}

1. Bolshaja sovetskaja entsyklopedija (1975). [The Great Soviet Encyclopedia]. Moscov, Vol. 22. 627 p. [in Russian].

2. Burluka, O. V. (2005). Samoosvita osobystosti yak sotsiokulturne yavyshche [Self-education of the personality as a socio-cultural phenomenon]. Extended abstract of candidate's thesis. Kharkiv, 16 p. [in Ukrainian].

3. Bukhlova, N. V. (2003). Orhanizatsiia samoosvitnoi diialnosti uchniv [Organization of self-educational activity of students]. Kharkiv, 64 p. [in Ukrainian].

4. Hromtseva, A. K. (1977). Samoobrazovanie starsheklassnikov obshcheobrazovatelnoj shkoly [Self-education of high school students of secondary school]. Leningrad, 119 s. [in Russian].

5. Disterveh, A. (1989). Rukovodstvo $k$ obrazovaniju uchitelej [A guide to teacher education]. Moscov, 412 p. [in Russian].

6. Komenskij, Ya. A. (1982). Izbrannye pedahohicheskie sochinenija [Selected Pedagogical Works]. Moscov, Vol.1.656 p. [in Russian].

7. Mark Avrelii (2007). Na odyntsi z soboiu. Rozdumy [Alone with you. Reflections]. Lviv, 212 p. [in Ukrainian].

8. Ozhehov, S. Y. (1986). Slovar russkoho yazyka [Dictionary of the Russian language]. Moscov, 798 p. [in Russian].

9. Pylypenko, Ye. O. (2011). Samoosvita yak pedahohichna problema [Self-education as a pedagogical problem]. Proceedings. Vol. 27, pp. 145150. Available at: http://nbuv.gov.ua/UJRN/ Nzkp_2011_27_22 (accessed 24 Apr. 2019). [in Ukrainian].

10. Rubakyn, N. A. (1982). Kak zanimatsa samoobrazovaniem [How to do self-education]. Moscov, 127 p. [in Russian].

11. Spenser, H. (1999). Opyty nauchnye, politicheskie ifilosofskie [Experimental, political and philosophical experiences]. Moscov, 1408 p. [in Russian].

12. Sukhomlinskii, V. O. (1977). Narodzhennia hromadianyna [Birth of a Citizen]. Selected works: in 5 volumes. Kyiv, Vol. 3, pp. 283-582. [in Ukrainian].

13. Ushynskyi, K. D. (1988). O polze pedahohicheskoi literatury [On the benefits of pedagogical literature]. Collected works in 2 volumes. Moscov, Vol. 2. 512 p. [in Russian].

Стаття надійшла до редакції 22.10.2019

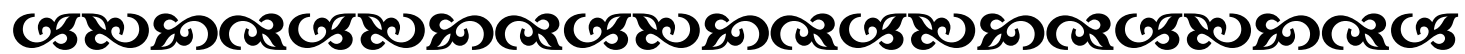

\author{
"Хто хоче багато досягти, повинен ставити великі вимоги".

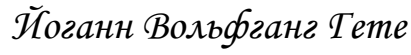 \\ німецький поет, прозаїк, драматург
}

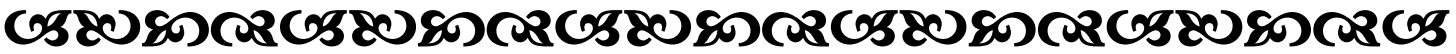

